\title{
LÍMITES A LA LIBERTAD DE EXPRESIÓN: DILEMA ENTRE CULTURA Y DERECHO *
}

\section{The boundaries of freedom of speech: dilemma between culture and law}

Miguel Rujana Quintero**

Recepción: 14 de marzo de 2016. Aceptación: 19 de julio de 2016. DOI: http://dx.doi.org/10.21017/Rev.Repub.2016.v21.a13

La libertad es la facultad de los seres humanos para determinarse a obrar según leyes de otra índole que las naturales, esto es, según leyes que son dadas por su propia razón; libertad equivale a autonomía de la voluntad.

Kant

La libertad es el conocimiento de la necesidad. Hegel La libertad es el conocimiento y dominio de la necesidad. Marx

\section{RESUMEN}

Este trabajo hace una mirada crítica a la jurisprudencia sobre la libertad de expresión en las democracias occidentales, específicamente al déficit jurídico relacionado con los límites por abusos a este derecho. Se describe la libertad de expresión, entendida por algunos tribunales nacionales e internacionales, y se ponen en evidencia incongruencias entre la declaración de derechos de libertad positiva y los límites que se establecen de libertad negativa, especialmente cuando se instrumentaliza por una posición dominante. Se concluye formulando algunas tesis sobre la precariedad de los límites que se intentan para restringir los abusos del derecho a la libertad de expresión, fijados por distintas jurisprudencias.

Palabras clave: Libertad de expresión, límites a la libertad de expresión, jurisprudencia interamericana, jurisprudencia europea, ofensa, daño moral grave, vis expansiva, injuria, calumnia, discriminación, minoría, velo islámico, islamofobia.

* Artículo producto del proyecto de investigación titulado Límites a la libertad de expresión: dilema entre cultura y derecho. Fue aprobado por la Universidad del Sinú Elías Bechara Zainúm, sede Bogotá, mediante Acta del Comité de Investigación, agosto 2015.

** Magíster en Derecho Público de la Universidad Santo Tomás (Colombia) con la Universidad de Konstanz (Alemania). Especialización en Filosofía de la Ciencia de la Universidad El Bosque. Especialización en Derecho Constitucional y abogado de la Universidad Libre. Docente investigador de la Universidad del Sinú, sede Bogotá. 


\begin{abstract}
This paper presents a critical view of freedom of speech jurisprudence in Western democracies, specifically of the juridical deficit related to the limits and abuses of this right. Freedom of speech is described herein as defined by some national and international courts, and incongruences are evidenced between the positive declaration of freedom rights and the limits that are established with negative freedom, especially when utilized by a dominant position. It concludes formulating some theses about the precarious nature of the limits that are intended to restrict the abuses of freedom of speech right set by different jurisprudences.
\end{abstract}

Key words: freedom of speech, limits to the freedom of speech, interamerican jurisprudence, european jurisprudence, offense, grave moral damage, expansive vis, injury, libel, discrimination, minority, islamic veil, islamophobia.

\title{
INTRODUCCIÓN
}

Este escrito se refiere a la necesidad de fijar nuevos límites a la libertad de expresión; y que estos límites se cumplan por los medios de comunicación contemporáneos de prensa, TV, cine, internet y redes sociales, realmente.

La problemática sobre los límites de este derecho partirá de su fundamentación y justificación, y seguido, se considerarán casos emblemáticos de discriminación y odios como las publicaciones infamantes o blasfemas ${ }^{1}$ contra la religión islámica efectuadas en Dinamarca y posteriormente en Francia, con la publicación del Semanario Charlie Hebdo, que ha tenido la característica de utilizar el humor para burlarse, a veces en forma ultrajante, procaz y grosera, de los personajes, su dignidad y creencias valoradas precisamente y con rigor como sagradas por los creyentes de la religión islámica. Igualmente, dicho diario ha dirigido sus burlas contra el cristianismo.

La libertad de expresión a través de los medios de comunicación se ha entendido como consustancial o insita a la democracia, en la medida en que la información que estos medios suministran permite a los ciudadanos ejercer la crítica

1 Blasfemia. Acepciones en sus dos significados. 1. Del lat. tardío blasphemia, y este del gr. âeaáöoçì?á blasphçmía palabra injuriosa'. 1. f. Palabra o expresión injuriosa contra alguien o algo sagrado. 2. f. Palabra o expresión gravemente injuriosa contra alguien o algo. Real Academia Española (C) Todos los derechos reservados. 
y el control de los actos de los gobernantes, evitando o paliando sus excesos, extralimitaciones e ineficacia de la gestión gubernamental.

En virtud del poder de los mismos medios como capaces de producir y «fabricar» percepciones, de difundir las opiniones de todo tipo, según la voluntad y concepción de los dueños de estos y la cultura dominante, de hacer aceptable y asumible por los usuarios y destinatarios, la libertad de expresión es un asunto que se cualifica cuando abandona su supuesta imparcialidad y objetividad, y acude a campañas difamatorias y calumniosas contra personas y gobernantes que no gozan de las simpatías ideológicas de quienes dirigen y poseen los grandes medios de comunicación.

Esto ha sido un asunto recurrente en América Latina. Particularmente en los casos de gobiernos reformistas como el de Joao Goulart en Brasil, Salvador Allende en Chile, y más recientemente con Chávez en Venezuela, los Kirchner en Argentina y Rafael Correa en Ecuador, con algunas importantes excepciones. Las respuestas de corte autoritario de algunos de estos gobernantes contra la libertad de expresión han provocado condenas, con los propios rechazos de estos gobiernos, por instancias internacionales, como la Comisión Interamericana de Derechos Humanos, $\mathrm{CIDH}^{2}$, pero sin atender la posible violación de límites en el ejercicio de ese derecho, incluso bajo los parámetros jurisprudenciales tradicionales de la injuria y la calumnia.

\section{PROBLEMA DE INVESTIGACIÓN}

El problema de investigación que orientó este ejercicio se sintetiza mediante el siguiente interrogante: $¿$ Existe la necesidad de una jurisprudencia coherentemente democrática que establezca los nuevos límites a la libertad de expresión a través de los modernos medios de comunicación, en el marco del Estado social de derecho? Es la pregunta que enfrenta el presente texto y la investigación de la cual hace parte, en los siguientes aspectos: a) frente a las convicciones religiosas de amplios sectores de la población, que con el carácter laico prevalente de las sociedades democráticas occidentales, siguen profesando el credo cristiano y católico; y b) frente a las convicciones religiosas de minorías que se han establecido de tiempo atrás en los países occidentales, y más acuciante aún, con la masiva emigración de refugiados del Oriente Medio, del Norte de África y de la región Subsahariana, la mayoría de ellos de religión musulmana.

En estas condiciones, plantear límites al ejercicio de la libertad de expresión significa asumir los retos de dos dilemas fuertes: (i) la confrontación entre

2 Casos tipos que serán referidos en este trabajo. 
cultura y derecho vigente, tal como es entendido por los tribunales de justicia nacionales e internacionales; (ii) y si el concepto de democracia demanda exigencias de transparencia, objetividad e imparcialidad para el ejercicio de la libertad de expresión, a través de los medios de comunicación, que se convierten, a su vez, en límites para dicho ejercicio.

\section{RESULTADOS}

La investigación demuestra que el marco jurídico del continente americano, y del Sistema Interamericano de Derechos Humanos sobre limites a la libertad de expresión es concordante y similar al europeo y al Sistema Europeo de Derechos Humanos; al mismo tiempo, que la forma de aplicar estos derechos difiere radicalmente entre uno y otro sistema. El motivo fundamental es la «razón de Estado» debido a circunstancias de «orden público» y «seguridad nacional», por las supuestas amenazas que representan las minorías étnicas y religiosas musulmanas, provenientes del Cercano Oriente.

\section{Orígenes}

La libertad de expresión es uno de los valores y derechos fundamentales que la humanidad ha luchado por conquistar, preservar y hacer efectivo desde los inicios de la sociedad. Al mismo tiempo, es el tesoro más esquivo, la condición más compleja y básica de entender y comprender. Es un bien común trascendente para la dignidad humana y para sus fines, para el sentido de la vida y para el ejercicio de la autonomía del ser humano. Supone una condición ética inescindible, que contribuye a alcanzar sus fines más elevados. Le permite al ser humano desplegarse y vivir en el mundo de su entorno, haciendo uso de todas sus posibilidades para conquistar el florecimiento de su vida, de su inspiración, ilusiones y sueños.

El derecho fundamental a la libertad de expresión (lenguajear) existe en tanto es lo propio y fundamental de lo humano. Es lo que lo distingue de otros seres vivos y, al mismo tiempo, hace que exista para el otro. Equivale a decir que sin este bien superior no somos nadie o, lo que es lo mismo, no existimos. Pues el ser humano es un ser de y para el lenguaje; la comunicación le da la posibilidad de existir y vivir como humano, de establecer la dinámica del lenguajear y el emocionar (Maturana H.) ${ }^{3}$.

3 Humberto Maturana (14-09-1928), reconocido biólogo y epistemólogo chileno, sostiene que «el lenguajear hace parte del sentido de lo humano, a partir de un sistema racional que tiene una base emocional que explica por qué no se puede convencer a nadie con un argumento lógico sino se ha aceptado antes su premisa a priori». 
Es a partir de este bien supremo que el ser humano se hace realidad, vive y no muere, como Jesús y Homero que aún sobreviven. Y es así como los derechos de libertad orientan la vida hacia los fines y valores que el ser humano se ha propuesto cumplir y hacer posibles, con el mayor esfuerzo y luchando contra sus limitaciones. En el ejercicio de la libertad no hay espacio para potestades absolutas, que son contrapuestas a a este derecho, ni tampoco para posibilitar acciones que atenten contra la integridad del ser humano, sus semejantes y su entorno. Es preciso que los seres humanos sientan la necesidad de expresarse sin más limitaciones que la propia inspiración dotada de razonabilidad y ética. Ya que se trata de un bien en sí mismo y no de un medio para alcanzar propósitos e intereses que atentan contra el otro y su dignidad.

Significa que el ser humano en ejercicio de este derecho se despliega en una doble configuración: de una parte, como ser natural que vive, piensa y siente la libertad con las limitaciones propias de su naturaleza y creatividad, y de otra, como ser social que es para el otro, para sus semejantes, representados por la sociedad y las leyes que se le han dado y en las que vive, para el ejercicio vivificante e intersubjetivo de sus derechos de libertad en el despliegue de la dignidad humana.

En esta dinámica, las leyes que los individuos de la sociedad se han dado no solamente constituyen derechos sino una limitación razonable a los derechos de libertad: una garantía social y una garantía individual. Protegiendo este sentido integral de la ley se salvaguardan los derechos individuales para la satisfacción de los bienes comunes. Los derechos absolutos y los ejercicios abusivos, así como las restricciones irrazonables e innecesarias, niegan la esencia de la libertad, ya que esta no consiste en hacer lo que nos plazca, sin considerar el respeto de la dignidad y la existencia de los derechos del otro y de su propia dignidad individual y colectiva, sino en posibilitar el florecimiento y el desarrollo de su autonomía, en el deber de encauzar sus facultades hacia el bien común y hacia los más altos valores e ideales que los definen y realizan.

Lograr una armonización y equilibrio de estos derechos no ha sido fácil: es la historia de la humanidad en sus luchas por la libertad. En todas las confrontaciones humanas por el poder social y político el hilo rojo que colorea estas disputas es la lucha por la libertad, el corolario de la acción y la decisión del ser humano, cualquiera que sea la forma que esta revista en su momento y lugar. Es posible que en la alegoría de Adán y Eva, ella haya reconsiderado el orden de las cosas, desobedeciendo al Dios de los hombres, para conquistar la «libertad que da el conocimiento».

Las historias de la Biblia (antigua y nueva) están adosadas de múltiples relatos de lucha por la libertad de expresión y de opinión, por la libertad de culto 
entre oráculos y religiones, y entre el monoteísmo y el politeísmo. Simultáneamente, están luchando por la libertad en sus propias formas, los griegos, los asirios, los persas, los asiáticos, los fenicios; pasajes bellamente ilustrados por Homero, entre otros. Luchas por la libertad que desde esa arcaica antigüedad no han cesado hasta hoy, no han dado tregua en ningún sentido.

Puesta en perspectiva de derechos humanos, se reseña como uno de los acontecimientos más significativos para el ejercicio de los derechos de libertad la limitación al poder consagrada en un documento memorable y fundante, la Carta Magna o la «Gran Carta» de 1215; debido a la violación sistemática que venían haciendo los reyes de Inglaterra a leyes y tradiciones antiguas, los barones, obispos y burgueses emergentes del reino obligaron al rey Juan I de Inglaterra, conocido como Juan sin Tierra, a firmarla, dando origen al constitucionalismo moderno. Se conoce igualmente como el primer acuerdo entre gobernados y gobernantes, de reconocimiento de los derechos de libertad, o lo que es lo mismo para esa época, de las limitaciones al poder: la obligación del gobierno a respetar los bienes de los ciudadanos, su derecho de herencia y a no ser obligados a tributar hasta la ruina, además del derecho a no ser detenidos ni juzgados arbitrariamente (origen del Habeas Corpus).

Otro hecho trascendental, político y social, que hace un quiebre radical en la historia de la humanidad con respecto a los derechos de libertad, fue el de la Revolución Francesa (siglo XVIII), que derrocó el hasta entonces poderoso absolutismo monárquico, que concentraba todo el poder en el rey. La ideología predominante que se inauguraba en este momento histórico en el que irrumpía el capitalismo y la democracia liberal fue precisamente la doctrina del liberalismo, entendida en principio como «libertad frente al Estado», como un valor propio de todo ser humano que empieza a significar al mismo tiempo límites al poder. Puede afirmarse, en consecuencia, que la libertad tiene un carácter histórico y que no siempre fue reconocida como un derecho, su afirmación estuvo ligada al desarrollo de las teorías del Estado como forma de organización política (Parra \& Góngora, 2004). Estas luchas por las libertades hay que honrarlas especialmente por las vidas que se han ofrendado para conquistarlas, y hay que exaltarlas por los importantes instrumentos y aportes que nos han legado: la razón ilustrada y el no menos importante derecho y el Estado demoliberal.

\section{Marco jurídico de la libertad de expresión}

De las proclamaciones constitucionales sobre la libertad de expresión, la doctrina más representativa de este derecho en las democracias occidentales se ha venido precisando en su contenido y alcances por los sistemas regionales de protección de los derechos humanos. De una parte, en el sistema interamericano 
que se fundamenta en los preceptos de la Convención Americana sobre Derechos Humanos o Pacto de San José de 1969 y sus Protocolos Facultativos especialmente, en la jurisprudencia de la $\mathrm{CIDH}$, y de otra parte, en el sistema europeo de protección de los derechos humanos basado en la Convención Europea de Derechos Humanos y los Pactos Internacionales de Derechos Humanos, y en la jurisprudencia del Tribunal Europeo de Derechos Humanos o Tribunal de Estrasburgo.

El sistema interamericano consagra y concibe el derecho a la libertad de expresión como una estructura nuclear de la cual derivan la autonomía, la dignidad y las posibilidades tanto para el libre desarrollo de la personalidad, para la existencia de los Estados democráticos, así como para su desarrollo permanente. Al mismo tiempo, advierte que no es un derecho absoluto, como ningún otro, lo cual significa que se debe ejercer con ponderación y proporcionalidad.

La Convención Americana sobre Derechos Humanos en su Artículo 13 traza la columna vertebral o principios fundamentales de la libertad de expresión y al mismo tiempo dispone un sistema propio y limitado de restricciones. Dicha normativa prescribe que:

1. Toda persona tiene derecho a la libertad de pensamiento y de expresión. Este derecho comprende la libertad de buscar, recibir y difundir informaciones e ideas de toda índole, sin consideración de fronteras, ya sea oralmente, por escrito o en forma impresa o artística, o por cualquier otro procedimiento de su elección. / / 2. El ejercicio del derecho previsto en el inciso precedente no puede estar sujeto a previa censura sino a responsabilidades ulteriores, las que deben estar expresamente fijadas por la ley y ser necesarias para asegurar: (a) el respeto a los derechos a la reputación de los demás, o (b) la protección de la seguridad nacional, el orden público o la salud o la moral públicas. // 3. No se puede restringir el derecho de expresión por vías o medios indirectos, tales como el abuso de controles oficiales o particulares de papel para periódicos, de frecuencias radioeléctricas, o de enseres y aparatos usados en la difusión de información o por cualesquiera otros medios encaminados a impedir la comunicación y la circulación de ideas y opiniones. // 4. Los espectáculos públicos pueden ser sometidos por la ley a censura previa con el exclusivo objeto de regular el acceso a ellos para la protección moral de la infancia y la adolescencia, sin perjuicio de lo establecido en el inciso 2.1. / / 5. Estará prohibida por la ley toda propaganda en favor de la guerra y toda apología del odio nacional, racial o religioso que constituyan incitaciones a la violencia o cualquier otra acción ilegal similar contra cualquier persona o grupo de personas, por ningún motivo, incluso los de raza, color, religión, idioma u origen nacional (Convención Americana sobre Derechos Humanos [CADH] Pacto de San José, 1969, pág. 4). 
Por su parte, la Declaración Americana de los Derechos y Deberes del Hombre establece el mismo nivel reforzado de garantías como lo hace la CADH. Prescribe: «Toda persona tiene derecho a la libertad de investigación, de opinión, de expresión y difusión del pensamiento por cualquier medio» (Declaración americana de los derechos y deberes del Hombre, 1984, pág. 6). En el mismo sentido, la Carta Democrática Interamericana, en su Artículo 4, señala que: «Son componentes fundamentales del ejercicio de la democracia la transparencia de las actividades gubernamentales, la probidad, la responsabilidad de los gobiernos en la gestión pública, el respeto por los derechos sociales y la libertad de expresión y de prensa» (Carta Democrática Interamericana, 2001, pág. 17).

La normativa de los instrumentos internacionales de derechos incluye los conceptos de dignidad y autonomía de la persona, y considera que el reconocimiento de la libertad de expresión no solo es un derecho derivado de la autonomía, sino que es un valor instrumental para el ejercicio de los demás derechos fundamentales y para el debido funcionamiento de los regímenes democráticos. En general, ambos sistemas de protección de los DD. HH. establecen que estos derechos configuran una relación estructural del derecho a la libertad de pensamiento y expresión con la democracia, lo cual genera una doble relación consistente en (i) el derecho de cada persona a expresar los propios pensamientos, ideas e informaciones, y (ii) de índole colectiva o social, consistente en el derecho de todas las personas a proferir y recibir cualquier información, a conocer los pensamientos e ideas ajenas, y a estar bien informadas (Corte Interamericana de Derechos Humanos, 2008, pág. 53). Sobre esta relación estructural o inescindible, se formulará más adelante una reflexión en el sentido de que se trata es de una relación simplemente estratégica.

La jurisprudencia de ambos sistemas de protección privilegia la libertad positiva de recibir y trasmitir, cuantas veces sea necesario, pensamientos, informaciones y opiniones; pero en este marco interpretativo, existe a nuestro juicio en torno a los límites de este derecho, un déficit pedagógico relacionado con la diversidad ideológica, sociocultural y religiosa, que caracteriza a las sociedades contemporáneas.

En consecuencia, es necesario un nuevo orden jurídico que incluya la pedagogía que exige la diversidad cultural, y permita anticipar los riesgos relacionados con las acciones de personas que disputan derechos a la libertad, en el marco de la diversidad religiosa, los nacionalismos y los fundamentalismos, comunes en y por el mundo globalizado de hoy, que hace que ciudadanos de todos los rincones del planeta emigren, especialmente, los de Oriente hacia Occidente, causando tragedias humanitarias, políticas y militares como las que vive actualmente Europa. En el presente año, por ejemplo, las migraciones superan el 
millón de personas, haciendo insuficientes los pronunciamientos jurisprudenciales referidos a la defensa de los derechos de libertad de información y opinión. Es necesario establecer los fundamentos acerca de los conceptos y verbos que gravitan los límites a estos derechos, que si bien están consagrados en los convenios interamericano y europeo, es conveniente interpretarlos a la luz de la globalización del mundo actual, que nos ha convertido en una aldea global que requiere una jurisprudencia global.

\section{La jurisprudencia de Occidente: aproximación a sus contenidos}

A continuación se presenta una muestra representativa de la jurisprudencia de los tribunales regionales y nacionales sobre el derecho a la libertad de expresión, de opinión, conciencia, pensamiento, a comunicar y recibir información veraz de cualquier naturaleza, con las observaciones críticas respectivas. Estos proveídos caracterizan en general el pensamiento de Occidente sobre libertad de expresión, centrados en establecer los límites tradicionales que dejan por fuera nuevos problemas y realidades del mundo contemporáneo, como los efectos socioculturales por la confrontación Oriente-Occidente o las exigencias de una democracia respetuosa de las minorías políticas, raciales y religiosas.

Los sistemas regionales de derechos humanos hacen referencia a la libertad de expresión; la definen como el derecho que tiene toda persona de expresar y difundir sus opiniones, ideas, pensamientos, narrar hechos, noticias y todo aquello que considere relevante, de una parte, y de otra, el derecho de toda persona a recibir información veraz e imparcial, lo que conlleva la libertad de fundar medios de comunicación que tengan por objeto informar sobre hechos y noticias de interés. Sobre los anteriores derechos de libertad positiva se precisará en este documento que la jurisprudencia no va más allá de hacer el reconocimiento de estos derechos, confirmando simplemente lo que ha caracterizado al ser humano: su capacidad de comunicabilidad con otros seres a través de uno de sus atributos, el lenguaje, potenciado por los medios tecnológicos modernos de la imprenta, la radio, la TV, el cine, la internet, etc.

La Corte Interamericana y el Tribunal Europeo de Derechos Humanos resaltan en sus jurisprudencias que la libertad de expresión y la democracia tienen una relación definida como «estrecha» e «indisoluble». Han expresado que esta relación lo que intenta es fortalecer el funcionamiento de sistemas democráticos pluralistas y deliberativos, mediante la protección y el fomento de la libre circulación de información, ideas y expresiones de toda índole; que esta relación del derecho a la libertad de expresión con la democracia se explica en parte por la doble dimensión de este derecho, individual y social. En efecto, como lo ha indicado la Corte Interamericana de Derechos Humanos, la libertad de expresión tiene un componente individual, consistente en el derecho de 
cada persona a expresar los propios pensamientos, ideas e informaciones, y uno de índole colectiva o social, consistente en el derecho de todas las personas a procurar y recibir cualquier información (ideas de toda índole relacionadas con la cultura, las tradiciones, las creencias, la política, la economía, etc.), a conocer los pensamientos, ideas e informaciones ajenos y a estar bien informadas (Corte Interamericana de Derechos Humanos, 2009).

Sobre esta relación estrecha e indisoluble existe controversia desde distintos ángulos del pensamiento. Se dice que es una relación estratégica y no estructural; en otros casos, que es necesaria sin ser suficiente. En todo caso, no es inescindible; pues la democracia a la que se refieren los sistemas regionales de derechos humanos es la que se plantea de modo ideal, haciendo abstracción de las insuficiencias, debilidades y falencias de los sistemas democráticos contemporáneos, ampliamente analizados en su momento por Norberto Bobbio en El futuro de la democracia (1986) y más recientemente, por Luigi Ferrajoli en su ensayo Poderes salvajes (2011).

La Corte Constitucional colombiana, en armonía con la jurisprudencia de la Corte Interamericana, señala que, además de ser inescindible, la libertad de expresión facilita la democracia representativa, ya que proporciona todos los elementos para la participación ciudadana. Este argumento subraya que «la comunicación y el libre flujo de informaciones, opiniones e ideas en la sociedad es un elemento esencial del esquema de gobierno democrático y representativo, por lo cual, la libertad de expresión, al permitir un debate abierto y vigoroso sobre los asuntos públicos, cumple una función política central». Señala:

Privar a una sociedad del principio de la libertad de expresión implica frenar el proceso colectivo de descubrimiento de la verdad y, en gran medida, impedir el desarrollo del conocimiento. Para que esta función pueda cumplirse a cabalidad no basta con el conflicto abierto entre interpretaciones de la realidad. Permitir una especie de intercambio libre de ideas es necesario pero no es una garantía suficiente, por sí sola, de que se llegará a la verdad puesto que unas versiones o posiciones pueden ser tan dominantes que las otras no sean divulgadas o lo sean esporádicas, aisladas y débilmente defendidas. De ahí que esta función se puede cumplir en condiciones de enfrentamiento equilibrado entre versiones antagónicas de la realidad. (Sentencia T- 391, 2007, pág. 2)

La jurisprudencia que se cita expone mecanismos para hacerse a la verdad sin fundamento práctico; al parecer, en virtud de una aplicación analógica de la competencia en la teoría del libre mercado o mercado de ideas, y que, por el contrario, el pensamiento filosófico científico lo ha considerado improbable. Veamos solo una lección con 2.500 años de antigüedad: 
«-¿Y de qué se alimenta el alma, Sócrates? - Desde luego, de enseñanzas, dije yo. De modo que, amigo, cuidemos de que no nos engañe el sofista con sus elogios de lo que vende, como el traficante y el tendero con respecto al alimento del cuerpo. Pues tampoco ellos saben, de las mercancías que traen ellos mismos, lo que es bueno o nocivo para el cuerpo, pero las alaban al venderlas; y lo mismo los que se las compran, a no ser que alguno sea un maestro de gimnasia o un médico. Así, también, los que introducen sus enseñanzas por las ciudades para venderlas al por mayor o al por menor a quien lo desee, elogian todo lo que venden; y seguramente algunos también desconocerán, de lo que venden, lo que es bueno o nocivo para el alma. Y del mismo modo, también, los que las compran, a no ser que por casualidad se encuentre por allí un médico del alma. Si tú eres conocedor de qué es útil o nocivo de esas mercancías, puedes comprar sin riesgo las enseñanzas de Protágoras y las de cualquier otro. Pero si no, ten cuidado, querido, de no jugar a los dados y arriesgarte en lo más precioso. Desde luego hay un peligro mucho mayor en la compra de enseñanzas que en la de alimentos. Pues al que compra comestibles y bebidas del mercader o del tendero, le es posible llevárselas en otras vasijas y antes de aceptarlas en su cuerpo como comida o bebida, le es posible depositarlas y pedir consejo, convocando a quienes entiendan, de lo que pueda comerse y beberse y de lo que no, y cuánto y cuándo. De modo que no hay en la compra un gran peligro. Pero las enseñanzas no se pueden transportar en otra vasija, sino que es necesario, después de entregar su precio, recogerlas en el alma propia, y una vez aprendidas retirarse dañado o beneficiado» (Platón, 1981, págs. 511-512).

La sentencia citada antes ha señalado que la libertad de expresión y la democracia son hechos inescindibles, y que una de las funciones de esta libertad dentro de los regímenes democráticos consiste en que permite buscar la verdad y desarrollar el conocimiento. Que cuando las diferentes opiniones y puntos de vista se enfrentan libremente en una sociedad pluralista, es más fácil para sus miembros decidir cuál de todas es la más cierta o la más adecuada, según el tipo de discusión que se esté dando. Sigue diciendo la sentencia que cuando lo que se expresa no sea cierto se debe corroborar y corregir. Argumento que es todo lo contrario a lo que pensaba el filósofo ya citado. Hay que decir que el conocimiento, como la verdad y la libertad, han recorrido siglos sin la ayuda de la democracia; al contrario, han servido para dar origen y conservar, con múltiples cambios, la que hoy tenemos, pues la originaria, la ateniense de Solón, Clístenes y Pericles, nació y murió con ellos, al hacerse con el poder el régimen de los Treinta Tiranos ${ }^{4}$, dando inicio a la democracia representativa.

4 Gobierno oligárquico de treinta magistrados impuestos por Esparta con la derrota de Atenas en la guerra del Peloponeso. 
Asombra el idealismo de la jurisprudencia cuando sostiene que es suficiente el intercambio de opiniones e información para que se fragüe en esta contienda la verdad, o al menos la posición más favorable, respondiendo a la práctica de la mayoría de las personas que no se inclinan por que lo que creen es lo cierto o lo más conveniente para todos; es decir, no lo hacen atendiendo a los mejores razonamientos sobre el interés y el bien común, sino en definitiva de conformidad con sus intereses particulares (económicos, ideológicos, religiosos, raciales, de género). Por supuesto, son estos intereses los que darían derecho a expresarse, hacerse públicos y someterse a debate abierto en la sociedad democrática de Occidente. En esta contienda propuesta por la democracia de Occidente se filtra por sus intersticios el poder del más fuerte, del más hábil, del tirano o del mercader del conocimiento y la verdad.

Es controversial la jurisprudencia de Occidente sobre la relación entre libertad de expresión y democracia como hecho inescindible, como si se tratara de valores de la misma naturaleza. Inescindibles son las partes que se pertenecen, que se necesitan y que no les es posible prescindir del otro, pues son parte de un mismo todo. Pero viendo de cerca el concepto, se podría asumir la discusión de que no es tan inescindible, pues la libertad de expresión es lo propio en el ser humano, independiente de que no se le reconozca y pueda ejercerla; y puede vivirse en cualquier comunidad, en cualquier tiempo moderno, y no necesariamente en la democracia que conocemos hoy. Pues de esta también se puede decir que pertenece a un complejo mundo variopinto: hay democracia participativa como en la comunidad de Clístenes; plutocrática, oligárquica como en la de los Treinta Tiranos de la antigua Grecia, socialista o capitalista. Habría que decir que lo inescindible es entre el Estado contemporáneo y la libertad de prensa, y no entre la democracia y la libertad de expresión, pues esta hace posible la vida y ha existido antes que el Estado y la democracia.

El alto tribunal colombiano ha indicado en la paradigmática Sentencia T-3912007 que la libertad de expresión contribuye a la formación de la opinión pública sobre los asuntos públicos y a la consolidación de un electorado debidamente informado, dado que materializa el derecho de los ciudadanos a comprender los asuntos políticos y les permite, así, participar efectivamente en el funcionamiento de la democracia, haciendo efectivo el principio de autogobierno representativo por parte de los ciudadanos mismos. Que es de responsabilidad de los gobernantes ante el electorado, controlar y revelar los asuntos relacionados con la vida del Estado y la sociedad misma. Por lo que renunciar a la libertad de expresión a través de los medios de comunicación equivale a renunciar al conocimiento general de los asuntos relacionados con el poder, sea en materia política, económica, militar o religiosa. Si bien este pensamiento abstracto es todo lo plausible que se quiera, aparece alejado y no corresponde a la realidad contemporánea en la mayoría de las democracias 
contemporáneas, en las que existe, eso sí inescindible, una relación entre los medios de comunicación y el poder político, que afecta la capacidad de información veraz y objetiva. Y si no, cómo explicar la desigualdad, la intolerancia, la inequidad que sufren los pueblos «informados» por estos medios.

En distintos pronunciamientos (Sentencia T-260, 2010, Sentencia C-010, 2000, Sentencia T-391, 2007, Sentencia C-442, 2011) la Corte Constitucional colombiana ha expresado que en la dimensión política, el derecho a la libre expresión cumple con las siguientes funciones principales: contribuye al debate político amplio y abierto que mejora la calidad en la elaboración de las políticas públicas, en la medida en que permite la inclusión de todos los sectores de la sociedad en los procesos de comunicación, decisión y desarrollo; mantiene abiertos los canales para el cambio político, impidiendo mediante la crítica que los gobernantes se arraiguen indefinidamente en una postura ilegítima; garantiza una protección sólida de la libre comunicación de información e ideas; previene los abusos gubernamentales de poder, al proporcionarles un contrapeso mediante la apertura de un canal para el ejercicio del poder ciudadano de participación y control de lo público. Es decir, que proporciona una oportunidad para la discusión de los asuntos de interés general, oportunidad que, a su vez, frena los riesgos de represión oficial; promueve la estabilidad sociopolítica, al proveer una válvula de escape para el disenso social y establecer, así, un marco para el manejo y procesamiento de conflictos que amenazan con socavar la integridad de la sociedad, que protege a las minorías políticas activas en un momento dado, impidiendo su silenciamiento por las fuerzas mayoritarias o prevalecientes; y a un nivel más básico, es una condición necesaria para asegurar la libre expresión de la opinión de los electores al depositar sus votos por un representante político.

En principio, resultan cargados de buenas intenciones los objetivos democráticos que se le trazan a los medios de comunicación y en general a la libertad de expresión, pero que chocan con una serie de fenómenos de la realidad política contemporánea en casi todas las democracias del mundo; a saber, el papel alienador y estimulador del control mismo de los medios de comunicación y particularmente de la televisión, para no hablar de los más modernos como internet. Ya en Los desafíos actuales de la democracia Michelangelo Bovero, quien sustituyó a Bobbio en la cátedra de la Universidad de Turín, indicaba a los 15 años de la obra de su maestro, acerca de cómo se habían agravado los vicios de las democracias contemporáneas y, en particular, señalaba el carácter desinformador de la programación televisiva en casi todos los países del mundo (Bovero, 2012). Y, recientemente, Humberto Eco en su última novela Número Cero, amén de divertida y perversa por el complejo mundo de suposiciones e imaginación, narra las más desconsoladoras intrigas que se fraguan entre los medios y el poder del dinero, haciendo que los límites entre la realidad y la 
mentira no signifiquen nada. Obviamente sin ceñirse a los más preclaros objetivos que le han señalado los tribunales de justicia (Eco, 2015).

La jurisprudencia de los tribunales nacionales e internacionales en el afán de defender la libertad de expresión del periodismo, como el predicado instrumento para el fortalecimiento de la relación «estructural» con la democracia, no reconoce que lo que hoy existe es la pérdida de representatividad de los mencionados partidos políticos, la desintegración de sus militancias, la pérdida de programas diferenciadores y la conversión de estos en simples vehículos de arribismo social, que no son más que un instrumento para la realización de intereses privados dominantes, del todo ajenos a los intereses de lo público. Tampoco les permite ver el aumento de los niveles de corrupción en las instancias gubernamentales y el agenciamiento por parte de los funcionarios públicos de los intereses del mundo de los grandes negocios, que en muchos casos obedece al financiamiento de las campañas electorales por parte de las grandes empresas y conglomerados.

A pesar de los significativos esfuerzos, lo más grave es que los altos tribunales no alcanzan a advertir la conversión de los medios de comunicación en grandes empresas comerciales, medios que en sus comienzos apoyaban la ideología y los programas de uno u otro partido, pero que hoy apoyan solo intereses de grupos económicos o políticos. Por tal motivo, poco les importa la abstracta prédica de la libertad de expresión de que hacen gala los tribunales de justicia nacionales o internacionales (convertidos en instituciones «útiles») y mucho menos reconocen la monopolización de los medios de comunicación, no solo del control de varios medios impresos, sino el de estos con los televisivos, lo que conduce a la producción de información y opiniones unívocas. Esto es la conversión del ciudadano en un individuo unidimensional y acrítico.

El modo como los altos tribunales de justicia entienden el derecho a la libertad de expresión y prensa pareciera concebirse para países imaginarios e inexistentes. En gran medida, como se ha señalado, no existe el periodismo imparcial e independiente. Los medios de comunicación están al servicio del poder y los gobernantes de turno y eso, para una actividad que se ha convertido en un rentable negocio, les reporta beneficios, representados en pautas publicitarias de las entidades públicas. Las temáticas que se abordan a través de los medios tienen que ver con la información oficial, las noticias de sangre, los desastres, los escándalos, la farándula, los deportes y toda clase de infortunios morales nada edificantes. Muy pocos medios promueven y permiten la crítica al poder, a los gobiernos y sus funcionarios. La razón la da la subsistencia de su patrimonio cultural y económico empresarial. Desde luego, hace parte del sostenimiento de la imagen de la libertad de expresión y de prensa de los medios, contar con «periodistas de opinión». 


\section{Límites a los derechos de libertad de expresión y prensa frente a los funcionarios públicos}

La Corte Constitucional colombiana reiteradamente ha hecho el reconocimiento de los derechos relacionados con la libertad de expresión y de prensa, pero aún no asume, o muy tímidamente lo ha hecho, el reto de fijar los límites que eviten el abuso a estos derechos; dotándolos de significación y explicando el contenido de los valores que se confrontan en el vértice de los límites. Como lo demuestra la larga experiencia periodística y las sentencias objeto de estudio, la prevalencia ilimitada de la libertad de prensa atenta con cierta regularidad contra la dignidad, la honra y las creencias de personas y colectividades. Las razones que válidamente justifican los límites a los derechos de libertad de expresión y de prensa se oponen al concepto de la vis expansiva $a^{5}$ que preferentemente adoptan los tribunales de justicia para amparar estos derechos y que, al parecer, no reconoce límites ni restricciones a los mismos.

Válidamente entendida esta vis expansiva, como consecuencia de considerar los derechos de libertad de expresión y de prensa como derechos de oposición (Duverger, M.) ${ }^{6}$, enfrentados al poder del Estado, estos garantizan al periodista y al medio, la posibilidad de expresar libremente sus ideas y opiniones, incluso en un tono duro, contundente, sarcástico, irónico e irreverente, sobre todo contra las autoridades y los aparatos del Estado. Cosa distinta e injusta es cuando al amparo de la vis expansiva, los derechos de libertad de expresión y de prensa se ocupan de informaciones y opiniones relacionadas con los particulares, grupos de personas o comunidades, eventos en los cuales el abuso y la extralimitación de esos derechos pueden ofender bienes jurídicos como la honra, la tranquilidad, la dignidad, el sentido de pertenencia cultural a una etnia o religión, que aunque desvirtuados judicialmente las ofensas, el honor, la buena imagen y el buen nombre, materialmente, nunca se restablecen.

La Corte Constitucional colombiana en Sentencia T-298-09 sobre los derechos de libertad de prensa cuando involucran a funcionarios públicos, consideró que «en temas de marcada relevancia pública en los que se encuentre involucrado un servidor público, el derecho a la libertad de expresión e información adquiere una mayor amplitud y resistencia», es decir, se autoriza la crítica hasta

5 Criterio de interpretación jurídica que privilegia con fuerza expansiva la libertad de expresión, sobre los límites.

6 Duverger, Maurice (06.05.1917 - 16.12.2014), jurista y politólogo francés. En su obra Instituciones Políticas y Derecho Constitucional. Ed. Tecnos, Madrid, 1970, señala que existen libertades límites; destaca la libertad-oposición, ejercida también por los medios de comunicación a fin de precaver el imperio fuerte de los gobiernos. 
el espacio de la intimidad del funcionario y contra este derecho no cabe acción de protección material alguna:

«Como se ha señalado, cuando una persona ha decidido voluntariamente convertirse en un personaje público o cuando tiene el poder de administrar de alguna manera el poder del Estado, tiene el deber de soportar mayores críticas y cuestionamientos que una persona del común que no ostenta poder público alguno y que no ha decidido someterse al escrutinio público» (Sentencia T-298, 2009, pág. 32).

En desarrollo posterior la Corte Constitucional colombiana indicó:

«Gozan de mayor grado de protección el discurso político, el debate sobre asuntos de interés público, y los discursos que constituyen un ejercicio directo e inmediato de derechos fundamentales adicionales que se vinculan necesariamente a la libertad de expresión para poder materializarse. Esta protección reforzada incide directamente sobre la regulación estatal admisible y el estándar de control constitucional al que se han de sujetar las limitaciones a este tipo de expresiones» (Sentencia C-442, 2011, pág. 5).

En esta forma, la jurisprudencia de la Corte se adhiere al concepto de la vis expansiva de los derechos de libertad de expresión y de prensa para el caso de controversias públicas o asuntos que comprometan el comportamiento de los funcionarios públicos, pero al mismo tiempo, abre las esclusas para que por esta vía se desborden las pasiones políticas, las intrigas, las prevenciones y cierta hostilidad que anima a muchos sectores sociales en contra de la llamada «clase política». Así, el ejercicio de estos derechos fácilmente cruza la línea de la injuria, la calumnia y la discriminación. $Y$ hasta los supuestos derechos al odio y a la ofensa.

Un ejemplo reciente que ilustra esa posibilidad es el pasado litigio del presidente Rafael Correa del Ecuador vs. Diario El Universo y el periodista Emilio Palacio. Este informador hizo imputaciones graves al mandatario señalándolo de «haber ordenado fuego a discreción y sin previo aviso contra un hospital lleno de civiles y gente inocente». Estas afirmaciones no se justificaron ni probaron en juicio, pasando a convertirse en acusaciones calumniosas que afectaron el buen nombre del presidente ecuatoriano.

El comunicador y el medio al que estaba vinculado creyeron encontrarse en ejercicio del derecho que les otorga la vis expansiva para denunciar hechos inmorales e ilícitos en los que al parecer habría incurrido el jefe del Estado. El fallo del tribunal nacional le dio la razón al mandatario, argumentando que se había, en primer lugar, faltado a la verdad como quiera que Correa había 
buscado refugio en un hospital, tras el motín de la policía que puso en riesgo su vida y no se encontraba, por tanto, en posibilidad de ordenar la operación de rescate realizada por el ejército. En segundo lugar, por ese motivo no se podía deshonrar la institución presidencial ni la figura del gobernante, ya que aquella y él gozan de especial protección y debido respeto.

Lo grave de esta clase de calumnias contra un alto funcionario estatal, cuando se desborda la vis expansiva y aun cuando se rectifique y los fallos sean adversos al promotor de las ofensas y daños graves, es que la dignidad del afectado y su familia queda seriamente lesionada, y más grave aún, se deteriora la confianza y credibilidad de los ciudadanos hacia el funcionario. No solo, por tanto, se afectó la honra de aquel, sino las condiciones básicas para el ejercicio democrático del poder, que en el caso ecuatoriano resultaban particularmente sensibles en un país en el que de 43 presidentes a lo largo de su historia republicana, solo 10 han concluido sus mandatos; esto es, sin haber sido derrocados por golpes militares o civiles.

\section{Jurisprudencia de Occidente en los límites a la libertad de expresión, culto y religión}

El tema controversial que ocupa el trabajo lo constituye el discernimiento acerca de los límites a la libertad de expresión y de prensa. Es sabido, como lo señalan las jurisprudencias citadas y la historia del derecho, que no existen derechos absolutos, excepto los del tipo de derecho a no ser torturado. El problema de los límites no es nada fácil, pues de una parte está lo que la filosofía de todos los tiempos ha llamado la naturaleza desafiante y conquistadora del ser humano y de otra, como dice la antropología, la domesticación del animalito humano para que acoja los límites. Tanto la filosofía como la sicología profunda han demostrado que hasta ahora ello no ha sido enteramente posible: lo humano es también díscolo, autocontradictorio, resistente a la defensa del bien común y esclavo de su propia inercia. Por ello no es nada fácil cuando de dirimir conflictos por medios pacíficos se trata. En esta tarea es al derecho y específicamente a la jurisprudencia a la que corresponde asumir semejante desafío: determinar los límites a la libertad humana y en particular a la libertad de expresión, no otorgando espacio alguno a la ofensa y al daño grave.

Este es el marco del presente esfuerzo y que comprende el dilema entre derecho y cultura; donde no es posible que el derecho determine la conciencia social o produzca los cambios que la sociedad requiere a fortiori; este se enfrenta a culturas y comunidades que aún viven en el pasado, con costumbres, modos y formas de vida que las determinan y por lo que están dispuestas incluso a entregar sus propias vidas, a pesar de lo que piensen otras sociedades que viven y sienten diferente, creando así las colisiones contemporáneas. 
La llamada civilización occidental que ha producido la ilustración y la modernidad ha desacralizado las creencias y valores del mundo antiguo, sus mitos y rituales; ha convertido lo divino en lo humano, como lo hicieron los hegelianos de izquierda trasladando los atributos de la divinidad al hombre como especie (Feuerbach). Ha proclamado la muerte de Dios al sostener que «Si Dios ha muerto, todo es posible para el hombre» (Nietzche); separando la ética de las convicciones religiosas, instaurando una ética racionalista (Kant) y utilitarista (Bentham), hasta llegar al simple hedonismo de la contemporaneidad, difundido ampliamente por los modernos medios de comunicación. Ha hecho de lo sagrado un mirar de soslayo, la ética una condición superflua; lo vulgar, trascendente y aquello que pareciera una ofensa hoy es simplemente algo coloquial. Los valores en el Oriente islámico son monolíticos, están contenidos y representados en el sagrado Corán: son uno y la misma ley, un solo dios, una sola ética, una religión y una política. Esa es la gran diferencia.

Con el criterio de reducir lo trascendental, que para muchos creyentes constituye sus creencias religiosas, en un asunto banal, se han producido ofensas que para algunos son graves. Es el caso emblemático, que al parecer ofendió a algunos ciudadanos colombianos por la publicación de la Revista Soho, en la que fueron fotografiados algunos destacados políticos de la vida nacional, tomando asiento en reemplazo de las figuras icónicas de los apóstoles en la Última Cena de Leonardo da Vinci. En la revista presidía la escena una conocida actriz que exhibía su busto desnudo en reemplazo de la figura de Cristo. El Juez 32 Penal del Circuito revocó el fallo proferido por el Juez 3 Penal Municipal, declarando la inexistencia de agravio alguno contra la fe católica y cristiana, y mucho menos, delito de injuria; que se trató de una simple alegoría del pasaje bíblico desde la inspiración del periodista, a la que tenía derecho en virtud de la libertad de expresión. Este es tan solo un ejemplo de cómo un derecho que se manifiesta laico puede resultar lesionando considerablemente los sentimientos y convicciones de un grupo respetable de ciudadanos. Aquí, desde luego, se plantea el problema de si la laicidad permite las ofensas, la burla e irrespeto injurioso de las convicciones de quienes profesan profundamente un credo o confesión religiosa y sobre el que se volverá más adelante. $\mathrm{O}$ dilema entre cultura y derecho.

En los límites a la libertad de expresión de la jurisprudencia se puede establecer que los factores comunes son la injuria, la calumnia; las faltas a la moralidad pública, al orden público, a la salud pública y a no ser discriminados; límites que son sustentados solo en algunos casos con el rigor debido. Entre las limitaciones, uno de los derechos que se amparan es el relacionado con la moralidad pública. Este concepto ha sido desarrollado en los tratados internacionales y en la jurisprudencia colombiana, coincidiendo en todos los casos 
que su interpretación debe ser especialmente restringida y definida de manera previa, clara y precisa. Esta no puede invocarse de forma abstracta para justificar una limitación; por el contrario, debe ser concreta, debe encuadrarse en la ley nacional y debe ser compatible con los principios esenciales de una sociedad democrática, con el Estado social de derecho y con el principio de la dignidad humana.

Se destaca el fallo colombiano del programa radial El Mañanero de la Mega de la cadena radial RCN. El programa se sancionó por no estar encaminado a preservar la moralidad pública y las buenas costumbres de la juventud, por las expresiones utilizadas, en emisiones con alto contenido de palabras soeces que además invitaban a la agresión, a la contra cultura y a la degradación del lenguaje y la riqueza cultural nacional. La Fundación Un Sueño por Colombia interpuso acción popular contra el Ministerio de Comunicaciones y Radio Cadena Nacional S.A. RCN, por vulneración «de la moral pública, las buenas costumbres, los valores, la integridad física y psíquica de la sociedad, y derechos colectivos como el patrimonio público, el patrimonio cultural de la nación, la seguridad y salubridad pública y los derechos de los consumidores y usuarios de radio en Colombia».

Para esta Fundación dicho programa «corrompe nuestra juventud y la envenena de la más variada gama de vulgaridad y patanería, constituyéndola así en un canal destructivo de los valores y la moral colectiva con sus transmisiones» (Sentencia T-391, 2007, pág. 13). Como consecuencia, la sentencia de tutela de la Corte Constitucional reafirmó las consideraciones del demandante, declaró probadas sus pretensiones y desestimó, en «choque de trenes», la providencia del Consejo de Estado que había fallado el caso otorgándole la competencia para decidir el asunto al Ministerio de Comunicaciones.

En el caso del Mañanero de la Mega, el juez de primera instancia denegó la protección a los derechos fundamentales de libertad de expresión y de información, argumentando que se había violado de manera directa la libertad de expresión stricto sensu, información y prensa protegidas en el artículo 20 de la Constitución colombiana, dado que se desconoció abiertamente la regla de neutralidad de las actuaciones estatales frente al contenido de las expresiones cuestionadas, al no ordenar directamente la adecuación de los contenidos de los programas en contravía de la jurisprudencia, y de los requisitos constitucionales sobre limitaciones a la libertad de expresión señalados en precedentes constitucionales vinculantes (Sentencia T-391 de 2007 y Sentencia T-260 de 2010).

Ahora bien, el derecho a la libertad de expresión, a difundir el pensamiento, la opinión e ideas por cualquier medio, es un derecho bien desarrollado en Occi- 
dente. Pero cabe preguntarse: ¿Hasta dónde esta libertad puede dejar sin amparo al individuo en sus derechos socioculturales? En un intento por mitigar esta desprotección, la Convención Americana de Derechos Humanos y el Pacto Internacional de Derechos Civiles y Políticos han señalado que se debe tener un respeto a los derechos y a la reputación de los demás y tener como finalidad una protección a la seguridad nacional, el orden público o la salud o la moral públicas, y que se guarde una neutralidad frente al contenido de la expresión que se limita; ha señalado la Corte Constitucional colombiana (Sentencia T-904, 2013).

De manera específica, las decisiones judiciales sobre el derecho a no ser discriminado por razón del culto y la religión son las que ponen a prueba la capacidad jurisdiccional del juez para aplicar los límites estrictos y la pedagogía requerida al derecho a la libertad de expresión. En estos temas se evidencia con claridad el dilema entre cultura y derecho. Veamos:

La sentencia T-200 de 1995 de la Corte Constitucional colombiana expuso las obligaciones que tiene el Estado frente a la libertad de cultos, según los instrumentos internacionales. En el caso, cuatro ciudadanas ejercieron acción de tutela contra la Arquidiócesis de Manizales por discriminación, debido a su estado civil y otros (una madre soltera, dos con unión marital de hecho y otra con matrimonio civil). Por estas razones no se les permitió el bautizo de sus hijos, a pesar de que todas profesan la fe católica. La Arquidiócesis argumentó que los hijos de aquellas eran «producto del pecado», por tratarse de «hijos naturales»y que el matrimonio civil no tenía ningún tipo de validez ante la doctrina católica. Por esta situación las madres interpusieron una acción de tutela buscando que el Estado protegiera los derechos de los hijos de las accionantes a ser bautizados.

Las accionantes expusieron la necesidad de la intervención estatal para obligar a las autoridades eclesiásticas a conceder y practicar un ritual, con efectos que son de rango eminentemente espiritual. En la providencia se expresa que el alcance y los límites a la libertad de cultos están garantizados por la Constitución Política en el Artículo 18, que aseguran la inviolabilidad de creencias religiosas, que no pueden ser afectadas por la actividad del Estado o por la injerencia de los particulares (Sentencia T-200, 1995). Destaca que:

Todos pueden afiliarse a la confesión religiosa de sus preferencias y, obviamente, habiéndose matriculado en una de ellas, el feligrés se compromete a acatar los deberes y obligaciones que exige la profesión de fe. Pero, desde luego, estas libertades no son absolutas. Han de ejercerse dentro del respeto al orden jurídico y a los derechos fundamentales de las personas. Su ejercicio abusivo, como el de cualquier otro derecho, está expresamente proscrito por el artículo 95, numeral 1, de la Constitución (Sentencia T-200, 1995, pág. 8). 
Igualmente la sentencia citada establece que:

Si bien el Estado se halla obligado por las normas constitucionales a permitir que los fieles de las distintas religiones tomen parte activa en los ritos propios de sus creencias, sin obstáculos ni impedimentos, siendo proscrita también cualquier gestión suya encaminada a forzar tales prácticas, pues la conducta oficial debe ser de total imparcialidad, los agentes estatales no pueden permanecer pasivos ante situaciones de esta naturaleza que, desbordando el curso razonable de las ceremonias religiosas, impliquen daño o amenaza a la vida, la integridad personal o la dignidad de los concurrentes o de terceros (Sentencia T-200, 1995, pág. 10).

De esta manera, asevera la Corte que ha existido, como es bien sabido, una división entre el orden eclesiástico que cada comunidad religiosa establece de modo independiente y los asuntos reservados a las competencias estatales. Así, el legislador mediante la Ley 133 de 1994 estableció que «las iglesias y confesiones religiosas tendrán, en sus asuntos religiosos, plena autonomía y libertad y podrán establecer sus propias normas de organización, régimen interno y disposiciones para sus miembros» (El Congreso de Colombia, 1994).

En este marco jurisprudencial, aunque la Constitución garantice el pluralismo religioso, y que el Estado no pueda interferir en el ordenamiento eclesiástico, el límite del desarrollo de sus actividades religiosas lo da el respeto al ordenamiento jurídico y a los derechos fundamentales de las personas. La sentencia es de gran importancia porque pone en evidencia los límites que tiene el Estado frente a las actividades lícitas de los particulares y especialmente acerca del respeto que se deben los semejantes por sus prácticas y ritos religiosos. Y porque es clara en señalar que no se impone límite a la forma de profesar la fe de las comunidades religiosas, sus ritos, atuendos y creencias.

La jurisprudencia latinoamericana también ha proferido sentencias relacionadas con los límites a la libertad de expresión. Uno de los casos fue el fallo de la Corte Interamericana de Derechos Humanos en el caso de la película La última tentación de Cristo. No tanto por la prohibición de exhibirla como por el derecho a presentarla (Sentencia La última tentación de Cristo, 2001).

El caso se origina por la prohibición efectuada por el gobierno chileno a la exhibición de la película. El argumento principal fue que la cinta resultaba ofensiva para importantes sectores de la población con respecto a la figura de Jesucristo, en su honor y reputación de orden teológico, y al derecho de un importante grupo humano que reivindica el derecho a no abandonar sus creencias de dos mil años, heredadas por sus familias y respaldadas por la mayoría de las instituciones nacionales. Los demandantes ante la CIDH alegaron que la 
prohibición de proyectar la película en referencia violaba el artículo 13 de la Convención Americana de Derechos Humanos, ya que esta señala que el ejercicio de la libertad de pensamiento y de expresión no puede estar sujeto a censura previa impuesta a la película, porque, al parecer, resultaba ofensiva a las creencias de un grupo de personas.

La Corte Interamericana de Derechos Humanos consideró que:

El Estado de Chile violó el derecho a la libertad de pensamiento y de expresión consagrado en el artículo 13 de la Convención Americana y concluyó que había incumplido los deberes generales de respetar y garantizar los derechos protegidos por la Convención al no adecuar el ordenamiento jurídico interno a las disposiciones de esta, y dispuso que el Estado debía modificar su ordenamiento jurídico interno, en un plazo razonable, con el fin de suprimir la censura previa para permitir la exhibición de la película (Sentencia de La última tentación de Cristo, 2001).

Argumentó que la exhibición del filme no priva ni menoscaba a ninguna persona su derecho de conservar, cambiar, profesar o divulgar, con absoluta libertad, su religión o sus creencias. Es suficientemente evidente que el fallo, aunque controversial a lo largo y ancho del continente americano y europeo por las implicaciones de orden religioso, terminó siendo una decisión técnica, pues el fondo del asunto se redujo al problema de censura previa y no al derecho a no ser discriminado por su orientación religiosa o de culto. Lo que significa que se perdió la oportunidad de desarrollar los contenidos que resuelven las demandas por las confrontaciones de fe.

La providencia a continuación es de importancia en una doble condición, de ser unificadora, y por el estudio comparado para fundamentar su fallo. Se destaca el estudio de varias sentencias de tribunales internacionales relativas a la libertad de expresión en materia religiosa; dejando en evidencia los argumentos contradictorios entre ellas y que permitirán controvertir la forma y el fondo jurídico de casos europeos y americanos sobre libertad de culto y religión.

En Sentencia T-832 del 2011 de la Corte Constitucional colombiana, magistrado ponente Juan Carlos Henao Pérez, se resolvió el caso de unas adolescentes que luego de estudiar 6 años en la Escuela Normal Superior Demetrio Salazar, solicitaron verbalmente el cupo al Programa de Educación Complementaria ofrecido por dicha institución. Las demandantes argumentaron que el cupo les fue negado porque no estaban dispuestas a usar pantalón; señalaron que por sus creencias religiosas las mujeres deben vestir faldas adecuadas a su género, ya que la Biblia dice que no vestirá la mujer traje de hombre, ni el hombre vestirá ropa 
de mujer, porque, abominación es, a Jehová tu Dios, cualquiera que esto hace. Por esta razón, en la acción de tutela solicitaron la protección de sus derechos fundamentales a la educación, a la dignidad, a la igualdad y al libre desarrollo de la personalidad.

La mencionada sentencia hace un estudio de derecho comparado, respecto de la colisión del principio de laicidad y de libertad religiosa en el ámbito de la educación, específicamente, por los usos de prendas que hacen parte del tocado y constituyen símbolo de una fe, como el velo en la cabeza para las musulmanas, los yarmulke para los judíos, los crucifijos para los católicos y cristianos, los cuellos y hábitos para las monjas, el bindi de las hindúes, la vestimenta de color azafrán de los budistas, los turbantes o los kirpan de los sijes o un atuendo de color rojizo para los seguidores del líder espiritual hindú Bhagwan Osho, crítico de todas las religiones ${ }^{7}$. La sentencia consultó los casos citados por el Tribunal Europeo de Derechos Humanos, de países como: a) Turquía, b) Suiza, c) Reino Unido, d) Canadá, e) Estados Unidos, f) Uzbekistán y g) Francia.

La sentencia también analizó el caso del Tribunal Europeo de Derechos Humanos (TEDH) de a) Sahin c. (vs) Turquía. Este litigio se refiere a la prohibición de ingresar a clases y presentar exámenes en la Universidad de Estambul a las alumnas que tuvieran la cabeza cubierta. La sentencia argumentó que el concepto de secularismo que se imponía estaba consagrado en el Artículo 9 del Convenio Europeo de Derechos Humanos. «El Tribunal entendió que, al examinar la cuestión del pañuelo islámico en el contexto de Turquía, había que tener presente el efecto que portar ese símbolo, que se presentaba o veía como obligación religiosa, podía tener en quienes optaban por no llevarlo; un efecto negativo» 8 :

El TEDH constató que la medida adoptada perseguía un fin legítimo, a saber, la protección de los derechos y libertades de los demás y la protección del orden público, mediante la salvaguarda de laicidad que garantiza la Carta Magna. También consideró que este principio, como garantía de los valores democráticos, constituye el nexo entre libertad e igualdad. Principio que impide que el Estado realice actuaciones tendientes a privilegiar a una religión en

7 BINDI DE LAS HINDÚES: Gota pequeña o punto de color rojo colocado en la parte central de la frente, utilizado en India y el Sudeste Asiático. TURBANTE: Es parte inseparable de la vida de los Sikhs en la India. El código de conducta Sikh señala que todos sus miembros deben usar un turbante como símbolo religioso. KIRPAN: Puñal que portan los Sijes de la India (siglos XVI y XVII) como un símbolo por la lucha contra la opresión y la injusticia. KIPPA, ídish o yarmulke: Pequeña gorra usada por los hombres, y últimamente por las mujeres judías.

8 Şahin v. Turkey, application No. 44774/98, ECtHR Chamber judgement of 29 June 2004, para. 108 and ECtHR Grand Chamber judgement of 10 November 2005, pag. 115. 
particular. Y sirve también para proteger a los individuos no solo de las hipotéticas injerencias arbitrarias del Estado, sino de movimientos extremistas (Sentencia T-832, 2011). El Tribunal negó el derecho a portar tocados de la fe religiosa.

Además, la sentencia de la Corte Constitucional colombiana consideró el caso del TEDH, b) Dahlab c. (vs) Suiza. En ese evento se inadmitió la solicitud de una profesora de escuela de llevar su tocado o pañuelo en la cabeza en el desempeño de su deber profesoral. El Tribunal sostuvo que una maestra que lleva un símbolo externo elocuente, como un pañuelo en la cabeza, puede tener cierto efecto proselitista en los menores, en este caso de 4 a 8 años de edad (Sentencia T-832, 2011). El Tribunal Europeo de Derechos Humanos le dio la razón al Tribunal de Suiza, y sostuvo además que la profesora podría tener una injerencia religiosa sobre sus alumnos, y quebrantaría el principio de neutralidad confesional de las escuelas. ${ }^{9}$ El Tribunal negó el derecho a usar tocados de la fe religiosa.

La providencia cita también el caso c) Reino Unido, Chamber of Lords Mandla c.(vs) Dowell. Controversia sobre integración y pluralismo cultural. El director de una escuela privada de confesionalidad cristiana negó la admisión a un alumno sijs que pretendía llevar a las clases un turbante, tal y como su religión lo prescribe. Se señala en la Sentencia que el director del centro escolar argumentaba que se aceptaban en el mismo, alumnos de todas las religiones y de todas las razas, pero no el uso del turbante sij que el alumno llevaba, manifestación exterior en exceso ostentosa de una fe no cristiana y, por tanto, contraria a las reglas del colegio. Incluso el estudiante se negó a portar una gorra acorde con el uniforme escolar, más en consonancia con el reglamento de régimen interno. Entonces, el padre del estudiante interpuso un recurso jurídico fundado en la Ley de Relaciones Raciales de 1976 que prohíbe discriminación directa o indirecta basada en la pertenencia a un grupo étnico. Tenía que demostrar que (i) su hijo recibió un tratamiento directo o indirecto a los otros alumnos, (ii) y que pertenecía a un grupo étnico (Sentencia T-832, 2011).

La Cámara de los Lores (Race Relations Amendment, 2000) consideró que los Sijs pueden beneficiarse de la protección de la Ley de 1976 porque sí constituyen un grupo étnico; por lo tanto, «dictaminó que el reglamento de la escuela

9 Dahlab v. Switzerland, application No. 42393/98, ECtHR decision of 15 February 2001. Segundo informe. E/CN.4/2006/5 9 de enero de 2006. COMISIÓN DE DERECHOS HUMANOS 62. ${ }^{\circ}$ período de sesiones. Tema $11 e$ ) del programa provisional LOS DERECHOS CIVILES Y POLÍTICOS, EN PARTICULAR LAS CUESTIONES RELACIONADAS CON LA INTOLERANCIA RELIGIOSA. Informe presentado por Asma Jahangir, Relatoría especial sobre la libertad de religión o de creencias. 
incurría en una segregación racial porque implicaba un tratamiento menos favorable que obedece a una discriminación directa basada en su pertenencia a una determinada comunidad religiosa» (Sentencia T-832, 2011). La providencia inglesa concedió el derecho a usar símbolos religiosos.

También se cita el caso d) Canadá en Singh-Multani c.(vs) Marguerite-Bourgeoys de 2006. «A un alumno perteneciente a la confesión religiosa sikh se le prohibió acudir al colegio con un símbolo religioso, un pequeño cuchillo metálico denominado kirpan, cuyas creencias religiosas le exigen llevarlo en todo momento» (Sentencia T-832, 2011). El tribunal canadiense determinó que al alumno se le infringió su derecho a la libertad religiosa; y que «las autoridades académicas tenían que demostrar que tal limitación de la libertad religiosa del estudiante se puede justificar en una sociedad libre y democrática». De la misma manera, «indicó que una prohibición general del empleo del kirpan, porque es símbolo de violencia, tendría efectos negativos en el ámbito educativo, entre ellos, reprimir la promoción de valores como el multiculturalismo, la diversidad y el desarrollo de una cultura educativa respetuosa con los derechos. En definitiva, se consideró que los efectos indeseables de una prohibición total de tal símbolo religioso sobrepasan sus efectos saludables (Sentencia T-832, 2011). ${ }^{9}$ La sentencia aprobó el uso de accesorios de la fe religiosa.

La sentencia analiza el caso de e) Estados Unidos en Arocha c. (vs). Needville Independent Scholl. El director de una escuela prohibió a un estudiante de 5 años utilizar dos trenzas largas como expresión de sus creencias religiosas; en razón, además, de que los estudiantes debían llevar el pelo corto. Los padres del menor interpusieron un recurso ante la Corte Estatal argumentando el respeto por las creencias religiosas de los estudiantes de diferentes religiones. En la respuesta a dicho recurso, con base en The Texas Religious Freedom Restoration Act (TRFRA), la Corte consideró que el menor tenía derecho a llevar la trenza como parte de su vestimenta. Los jueces del caso explicaron que en las disputas sobre libertad de ejercer la creencia religiosa:

«Se define caso por caso y depende de las circunstancias individuales». Y agregaron que «imponer al estudiante cortar su pelo constituía un prohibición realmente pesada considerando el largo tiempo que pasa en la escuela (...) significa para el estudiante elegir entre renunciar a sus creencias religiosas o renunciar a atender la escuela pública de Needville» (Sentencia T-832, 2011).

La providencia estadounidense concedió el derecho a usar símbolos religiosos.

9 Tribunal Supremo de Singh-Multani c. Marguerite-Bourgeoys (1 S.C.R. 256, 2006 SCC 6). 
La sentencia relacionó el caso f) Hudoyberganova c. (vs) Uzbekistán (Asia Central). Una estudiante musulmana fue suspendida de un instituto académico, al parecer, por llevar la cabeza cubierta. En este caso, se demandó el derecho a llevar los tocados ante el Comité de Derechos Humanos de la ONU. Este resolvió que la religión comprende el derecho a llevar en público un atuendo que esté en consonancia con la fe o la religión de la persona. Además, consideró que impedir a una persona que porte prendas religiosas en público o en privado puede constituir una violación del párrafo 2 del artículo 18 del Pacto, que prohíbe toda medida coercitiva que pueda menoscabar la libertad de una persona de tener o de adoptar una religión.

El Tribunal concedió el derecho a portar tocados de la fe religiosa.

La providencia T-832-91 tuvo en cuenta el caso g) Ley francesa de 2010, S.A.S. c. (vs) Francia. Después de un intenso debate en el seno de la sociedad francesa, el Estado estableció la prohibición de portar en lugares públicos, prendas de vestir diseñadas para ocultar el rostro como el Hijab, Chador, Niqab, Burka y pasamontañas ${ }^{10}$. La ley fue demandada ante el Consejo de Estado francés, quien encontró la disposición normativa ajustada a la Constitución y al CEDH. La demandante argumentó que la prohibición genera una discriminación basada en razones de sexo, religión y origen étnico incompatibles con el artículo 14 de la Convención Europea de Derechos Humanos; sobre todo si se tiene en cuenta las excepciones legales que introduce, permitiendo ocultar el rostro en público en el contexto de festividades o eventos artísticos o tradicionales (no religiosos).

La accionante no solo ve en la Ley 1192 un trato discriminatorio sino profundamente confuso, puesto que de una parte privilegia la mayoría cristiana que sí puede realizar eventos o procesiones religiosas y hasta carnavales para recolectar fondos, también con prendas alusivas a sus símbolos sagrados, que en algunos casos ocultan el rostro; de otra parte, permite la celebración de eventos públicos o privados relacionados con obras de teatro y carnavales en los que también se cubre el rostro. Respecto de poner en peligro la seguridad pública, la demandante considera que no puede ser de recibo para amparar la limitación de los derechos consagrados en el art. 9, de la CEDH, pues desde el

10 BURKA: Es una prenda que cubre todo el cuerpo y tan solo posee una rejilla a la altura de los ojos que limita la visión lateral. En Afganistán el manto cubre hasta las manos y es el más usado. NIQAB: Esta prenda cubre el rostro y va hasta la rodilla, tapa el cabello y cuello, solo deja libres los ojos. Es usado principalmente por las mujeres en los Estados del Golfo. HIYAB: Es prenda que caracteriza a las mujeres árabes, cubre el cabello y el cuello dejando libre la cara. En algunas regiones se combina con el niqab. PASAMONTAÑAS: Gorro de lana o punto que cubre toda la cabeza y el cuello dejando al descubierto la cara o solo la zona de los ojos; es una prenda usada para protegerse del frío o para no ser reconocido, como un derecho extremo a la intimidad. 
momento en que no se trata de una medida dirigida a solucionar preocupaciones concretas por la seguridad en ciertos lugares, entonces es una prohibición «general» y solo para afectar a la comunidad religiosa musulmana. También, la Ley en mención restringe el pluralismo cultural, social y religioso de las minorías, consagrado en la Constitución y en múltiples jurisprudencias.

El gobierno francés mediante la Ley 1192 del 2010 prohíbe el uso de prendas religiosas que cubren el rostro.

Human Rights Watch y otras ONG han argumentado desde la promulgación de la Ley francesa en 2010, que la prohibición de portar prendas religiosas resulta discriminatoria y violatoria de los derechos de libertad religiosa y de expresión de las personas que optan por usar el nicab o burka; que prohibiciones de esta sean formuladas en términos neutros o mediante referencias explícitas al velo musulmán tienen un impacto desproporcionado sobre las mujeres musulmanas y, por lo tanto, violan el derecho a no sufrir discriminación por motivos de religión y género, de que trata el numeral 5 del artículo 13 de la CADH y los artículos 9 y 14 de CEDH; que el fallo del Tribunal Europeo simplemente le señala al gobierno el deber de obrar con proporcionalidad y revisando cada caso concreto. La investigadora para Europa Occidental de Human Rights Watch señala que debe adoptar en los casos el principio de convencionalidad y de acuerdo con los fundamentos de la CEDH (Leghtas, 2014).

La Corte Constitucional colombiana (Sentencia T-832, 2011) concluyó su caso a partir del estudio comparado anterior, argumentando que los límites al ejercicio de la libertad de expresión religiosa están relacionados con la seguridad, la salud y la moralidad públicas como elementos constitutivos del orden público, y cada una de las medidas adoptadas deben estar acordes con la aplicación del principio de proporcionalidad entre el principio de laicidad y neutralidad del Estado y la manifestación de la libertad religiosa. Por lo anterior, para el caso en concreto, la Corte decidió conceder el amparo de los derechos fundamentales a la libertad religiosa, y al libre desarrollo de la personalidad de las jóvenes. Es decir, la Corte se sumó a la mayoría de los tribunales comparados (los siete casos), concediendo el derecho a usar prendas que constituyen símbolos religiosos.

De otra parte, la Ley francesa 1192 de 11 de octubre de 2010, que entró en vigencia el 11 de abril de 2011 y que restringe el uso de prendas religiosas que oculten el rostro, fue demandada ante el Tribunal Europeo de Derechos Humanos (TEDH), quien decidió su exequibilidad el 1 de julio de 2014.

La normatividad ampliamente controversial amerita ser objeto de estudio a fondo en otra investigación. No obstante, hay que anticipar que es contradic- 
toria e inconsistente con la mayoría de las providencias citadas en la sentencia anterior y en este escrito. Además, no corresponde a la tradición y a la filosofía política y libertaria del pueblo francés. Los argumentos parecieran ser contra los que combatieron Voltaire, Michel Foucault y tantos otros que lucharon contra la política de la sospecha, la intimidación y el terror de Estado.

El tribunal consideró que las disposiciones de la circular atacada no violaron las estipulaciones del artículo 9 del Convenio Europeo de los Derechos Humanos y Libertades Fundamentales, ni las del artículo 18 del Pacto Internacional de Libertad de Pensamiento, de Conciencia y de Religión, porque la prohibición enunciada por la ley, y aplicada por la circular, no es excesiva, especialmente considerando el fin de interés general que está en su objeto, es decir, el respeto del principio de laicidad en las escuelas públicas (Fallo del 8 de octubre de 2004).

Los argumentos del Tribunal Europeo precisan que las limitaciones previstas en el artículo 9.2 de la ley en cuestión se ajustan a sus preceptos y principios en el sentido de que es una necesidad la prohibición de portar el velo en una sociedad democrática, ya que es conveniente y válida fundamentalmente por la obligación de asumir el mayor nivel de neutralidad por parte del Estado (Sentencia del TEDH en el asunto S. A. S., 2014).

La sentencia del Tribunal Europeo destaca la posición del gobierno francés en la medida que «entiende que la alegada contradicción entre la ocultación del rostro por las mujeres y el principio de igualdad de género es simplista, y que la supuesta vulneración de la dignidad humana es una asunción abstracta basada en una lógica estereotipada y chovinista» (Sentencia del TEDH en el asunto S. A. S., 2014, pág. 3); que no todo acto motivado o inspirado por la religión está protegido, y que en una sociedad democrática es necesario establecer limitaciones, por más que el Estado tenga la obligación de observar una posición de neutralidad e imparcialidad en su tarea de mediador del ejercicio de las diferentes religiones, creencias y confesiones que conviven en su ámbito territorial. Esta obligación de neutralidad es incompatible con una valoración por parte del Estado acerca de la legitimidad de las creencias de sus ciudadanos o de la forma en que se expresan.

De la misma manera, establece la sentencia del Tribunal Europeo que se justifica la limitación en abstracto para garantizar las condiciones de la vida en común y además porque la medida iría tan solo contra un pequeño número de mujeres (ocho millones de musulmanes en Francia, el 13\% de la población), que serían eventualmente las afectadas. Pero ganarían en beneficios porque se reduciría el impacto negativo del elemento islamófobo, el riesgo de consolidar estereotipos y fomentar expresiones de intolerancia. Que cubrirse el rostro 
supone una barrera frente a los demás, y el Estado lo considera como una violación del derecho de los otros a vivir en un espacio de socialización. En este sentido, no se puede socializar con otros, porque se tiene el rostro cubierto (Sentencia del TEDH en el asunto S.A.S., 2014).

El argumento final del Tribunal sobre la prohibición queda reducido a la afirmación de que el Estado francés debe en este caso disfrutar de un «amplio margen de discrecionalidad» en su tarea de dirección política como agente mejor situado para evaluar las necesidades y condiciones locales, frente al cual el Tribunal tiene un «deber de ejercitar un grado de restricción en su control de convencionalidad» de la prohibición. No obstante, considero que la ley francesa no violó la CEDH.

El Tribunal Europeo sostiene que el Estado francés, lejos de justificar una sociedad democrática, protege la decisión de la mayoría de la sociedad de hacer primar sus valores sobre el estilo de vida y la vestimenta religiosa de la minoría. Es, sin duda, un argumento de pluralismo selectivo y de tolerancia restringida, contrarios a la jurisprudencia del TEDH, según el cual, el papel de los Estados no es eliminar las tensiones sociales reduciendo o suprimiendo el pluralismo, sino reforzándolo y tolerándolo.

No obstante el Tribunal aclara que no es necesario que en una sociedad democrática, pluralista y tolerante, en la que debe asegurarse la búsqueda continua del equilibrio que garantice el trato correcto de las minorías, se afecte el derecho de toda persona a su identidad cultural y religiosa, razón por la cual, la misión del Tribunal es proteger a las minorías frente a cualquier posible injerencia «desproporcionada». Argumento que es deleznable o que simplemente cae al vacío ya habiendo declarado la exequibilidad de la Ley francesa en cuestión.

Una muestra representativa y muy significativa del dilema entre cultura y derecho es el caso del periódico satírico francés Charlie Hebdo, semanario que comunica expresiones deshonrosas en el formato de comics, caricaturizando los más respetados iconos sagrados de la religión cristiana y musulmana. El 11 de enero del 2015, dos musulmanes yihadistas abrieron fuego y dieron muerte a diecisiete personas, entre ellas nueve trabajadores del semanario, por las caricaturas ofensivas que venían publicando de tiempo atrás contra la persona venerada de Mahoma.

La tragedia inicialmente convocó la solidaridad del mundo entero hasta el punto que decenas de mandatarios presidieron las honras fúnebres en la Plaza de la República colmada de seguidores franceses y de otros países con la etiqueta «Je suis Charlie», en defensa de la libertad de expresión, de pensa- 
miento, de opinión, de conciencia y del periodismo. En este acto luctuoso se exhibieron nuevamente las caricaturas contra el Islam, el Cristianismo, el Catolicismo y otros iconos representativos de lo sagrado: caricatura de Mahoma que perdona a los blasfemos con el letrero Je suis Charlie; Jesús levitando en las aguas mientras un niño musulmán se ahoga en el fango (como una crítica al cristianismo por su incapacidad que no lo salva); la Santísima Trinidad en una orgía sexual: Dios detrás del Espíritu Santo y este, de Jesús, entre muchas otras. Pero al poco tiempo la reflexión vuelve al pináculo de la razón ilustrada y confronta al derecho de la libertad de expresión; el primer estamento avergonzado: los jefes de Estado que presidieron los actos luctuosos, quienes al día siguiente recibieron la crítica, como enemigos de Oriente (su cultura y su religión). Para la muestra, muchos periódicos europeos y varios medios británicos y estadounidenses los desautorizaron al negarse a mostrar la imagen de Je suis Charlie sobre el cuerpo de Mahoma, para evitar herir al mundo musulmán. Lo que se creyó un triunfo por la libertad absoluta de expresión se convirtió en un lánguido comunicado de «no a los atentados contra las vidas inocentes...», y con más fuerza en los últimos tiempos ya se empieza a leer en twitter el hashtag «Je ne suis pas Charlie» («No soy Charlie») o Charlie ya no es Charlie o, lo que es peor, ya se ha convertido Je suis Charlie en una caricatura.

Algunos países han convertido el hecho en un motivo para revivir el espíritu de cohesión nacional y de rechazo a la violencia y una oportunidad para reconsiderar los límites a la libertad de expresión.

En 1988 el novelista indio nacionalizado británico, Salman Rushdie, escribió «Los Versos Satánicos». La publicación fue prohibida y quemadas sus ediciones en los países musulmanes, causando desórdenes y manifestaciones en todos los países de esa confesión, y aun en Inglaterra y Estados Unidos. El 14 de febrero de 1989, el Ayatolá Jomeini pidió a la población musulmana ejecutar a cualquier persona relacionada con la obra y una recompensa en dinero efectivo para el que diera muerte al escritor. Las ofensas de esta fecha a hoy no han cesado; se ha intentado ante tribunales europeos y estadounidenses frenar el abuso al derecho de libertad de expresión, amparado en el CIDH y el CEDH, y no ha sido posible que esta confrontación de derechos logre una solución satisfactoria.

Hace cinco años el periódico Charlie Hedbo y otros medios satíricos europeos publicaron caricaturas contra Mahoma y su religión. Solo hubo algunas amonestaciones por las transgresiones a los límites, pero la jurisprudencia y los Estados no le han dado la importancia que requiere implementar una pedagogía jurídica del respeto a lo que se considera sagrado para núcleos importantes de población. En enero de 2015, el abuso a los límites cobró las 17 primeras 
vidas humanas por estos hechos y la respuesta del gobierno francés fue abrir 17 frentes militares en Oriente Próximo y Norte de África. Como retaliación, el pasado 13 de noviembre un atentado suicida del EI (Estado Islámico) dejó 129 muertos y 350 heridos. En respuesta, el Estado francés lidera una coalición de Estados europeos para enfrentar el desafío del Estado yihadista. Lo grave de esta situación es que la primera víctima, como siempre, será la verdad y, consecuentemente, la libertad de expresión.

\section{CONCLUSIONES}

Uno de los postulados de la jurisprudencia en las democracias occidentales que se encontró a lo largo de la exposición y que constituye la piedra angular de la libertad de expresión es la llamada relación «inescindible» entre libertad de expresión y democracia. Sobre el particular es válido concluir que se trata de un principio susceptible de profunda crítica, ya que de una parte la libertad de expresión acompaña al hombre desde el principio de los tiempos y la democracia es apenas una forma de gobierno demasiado joven. El proceso de la construcción de la democracia en Occidente demuestra que la libertad de expresión y de prensa no siempre se ha avenido cómodamente con las democracias liberales, como lo señala Alan Wolfe en su clásica obra «Los límites de la legitimidad: contradicciones políticas del capitalismo contemporáneo». Así que no se trata de una relación inescindible sino apenas estratégica (Wolfe, 1997).

Sobre la interpretación de las reglas relacionadas con los límites a la libertad de expresión como la injuria, la calumnia y la discriminación convertidos en instrumentos de abuso del derecho a la libertad de expresión, creemos que no se debería pedir a los jueces que hagan de ellas una interpretación restrictiva, so pretexto de favorecer la vis expansiva, sino que se debe prescindir de este criterio en cuanto sea posible; es decir, se debería invertir el criterio de interpretación, pues solo a través de límites robustos y de una pedagogía jurisprudencial rigurosa se pueden contener los abusos del derecho, especialmente cuando se producen expresiones que ofenden la moral, la ética, lo sagrado o lo significativamente honroso para personas y comunidades. Debe agregarse que la teoría de la vis expansiva, así como la interpretación restrictiva, resulta claramente contradictoria con las tendencias crecientes y con los conceptos de injuria, calumnia y discriminación que la misma Corte Interamericana ha establecido para enfrentar estos injustos, cuando definiéndolos, sostiene que son «actos objetivamente ofensivos y que menoscaban la estima y la fama de la persona afectada. Además, quien la emite tiene intención de que tal cosa suceda, atenta contra el honor del injuriado, por ejemplo, atribuyéndole hechos que sabe falsos». En la calumnia se va más allá, 
imputándole al calumniado falsamente la comisión de un delito o de un hecho deshonroso.

La jurisprudencia debe desafiar y explorar alternativas para formular los fundamentos, teorías y demás formas que expliquen las situaciones de límites. Su trabajo no solo es insistir en la confirmación de los derechos positivos que de tanta recurrencia ya se encuentran agotados y cosificados; no está en continuar describiendo lo que caracteriza al ser humano: su lenguaje, que la lingüística, la antropología, la filosofía analítica y muchas otras ciencias han elaborado con lujo. El reto es desarrollar una cultura de la convivencia, del respeto al otro, al semejante, a la diversidad; es promover la construcción de comunidad incluyente y diversa, que defienda y reafirme a las minorías y que promueva el desarrollo de la democracia y la sociedad; que el poder de la mayoría se circunscriba a los procesos electorales para la renovación alternativa del poder.

Pero resulta difícil que las sociedades puedan resolver sus diferencias con un mínimo de justicia «estándar», transparente y predecible. Lo que hoy sostiene la jurisprudencia de un país o un tribunal internacional resulta desconocido, autocontradictorio y contradictorio por los otros tribunales, como lo demuestran las providencias traídas a colación en la Sentencia T-832 de 2011 de la Corte Constitucional colombiana y cuyos criterios sobre el tema religioso son desconocidos u omitidos; también por el Tribunal Europeo de Derechos Humanos, quien le dio la razón al Estado francés con respecto a la prohibición del uso del velo por parte de las mujeres musulmanas, a pesar de ser contradictorio con varias de las sentencias citadas.

Sin duda, la libertad de expresión y su manifestación a través de los medios de comunicación constituye hoy la piedra de toque de una jurisprudencia que no ha sido capaz de encontrar soluciones justas frente a los abusos de estos derechos en materia religiosa. Jurisprudencia que sigue atada a principios de laicidad y neutralidad del Estado, que en sus expresiones extremas justifican el agravio a las convicciones y creencias arraigadas de minorías étnicas, pero también, de un grupo numeroso de personas originarias de los respectivos Estados nacionales.

La búsqueda de soluciones legales y jurisprudenciales adecuadas y correctas para enfrentar los conflictos nacidos del choque de culturas (OrienteOccidente) o dilema entre cultura y derecho se torna hoy más urgente que nunca, cuando el odio y el resentimiento de unos y la desconfianza, el desprecio y la marginación procedentes de los otros amenazan con destruir toda forma civilizada de convivencia como nunca antes en la reciente historia de la humanidad. 


\section{REFERENCIAS}

Bobbio, N. (1986). El Futuro de la Democracia. México: Fondo de Cultura Económica.

Botero M., C. (2013). Jurisprudencia nacional sobre libertad de expresión y acceso a la información. Comisión Interamericana de Derechos Humanos.

Bovero, M. (15 de noviembre de 2012). Los desafíos actuales de la democracia. Obtenido de http:// biblio.juridicas.unam.mx/libros/8/3923/pl3923.htm: http://www. plataformademocratica.org/Publicacoes/5811.pdf

Carta Democrática Interamericana. (2001. p. 17). Organización de los Estados Americanos. Artículo 4. Washington, DC.

Congreso de Colombia. (23 de mayo de 1994). Ley 133. Por la cual se desarrolla el Decreto de Libertad Religiosa y de Cultos, reconocido en el artículo 19 de la Constitución Política. Bogotá, Colombia.

Convención Americana sobre Derechos Humanos, Pacto de San José. (22 de noviembre de 1969). Artículo 13. Libertad de Pensamiento y de Expresión. San José, Costa Rica.

Corte Interamericana de Derechos Humanos. (25 de febrero de 2009). Relatoría Especial para la Libertad de Expresión. Una agenda hemisférica para la defensa de la libertad de expresión. Organización de los Estados Americanos.

Declaración Americana de los Derechos y Deberes del Hombre. (1984). Artículo 4 Derecho de libertad de investigación, opinión, expresión y difusión. Aprobada en la Novena Conferencia Internacional Americana Bogotá. Bogotá, Colombia.

Eco, H. (2015). Número Cero. Lumen.

Ferrajoli, L. (2011). Poderes salvajes. Madrid: Trotta.

Leghtas, I. (03 de julio de 2014). Sentencia sobre uso de velos que cubren el rostro atenta contra derechos. Obtenido de https://www.hrw.org/es/news/2014/07/03/ francia- sentencia-sobre-uso-de-velos-que-cubren-el-rostro-atenta-contra-derechos

Parra, O., \& Góngora, M. (2003). Derechos de Libertad. Defensoría del Pueblo. Bogotá: Serie Red Nacional de Promotores de Derechos Humanos.

Platón. (1981). Protágoras en Diálogos. Madrid: Editorial Gredos.

Race Relations Amendment, Ley de Relaciones Raciales de 1976 (2 de abril de 2000). 
Sentencia C-010 (Corte Constitucional de Colombia, 19 de enero de 2000).

Sentencia C-442, M. P. Sierra Porto, Humberto Antonio (Corte Constitucional de Colombia, 25 de mayo de 2011).

Sentencia de Apelación de Sentencia de Amparo. Expediente 4628-2009. (Corte de Constitucionalidad de Guatemala, 14 de septiembre de 2010).

Sentencia La Última Tentación de Cristo, Olmedo Bustos y otros vs. Chile (Corte Interamericana de Derechos Humanos, 5 de febrero de 2001).

Sentencia del TEDH en el asunto S. A. S., Núm. 43835/2011, ECHR (Consejo General del Poder Judicial, Manuel Olmedo Palacios, 2014).

Sentencia T- 391, M. P. Cepeda Espinosa, Manuel José (Corte Constitucional, 22 de mayo de 2007).

Sentencia T-200, M. P. Hernández Galindo, José Gregorio (Corte Constitucional de Colombia, 9 de mayo de 1995).

Sentencia T-260, M. P. González Cuervo, Mauricio (Corte Constitucional de Colombia, 16 de abril de 2010).

Sentencia T-298, M. P. Vargas Silva, Luis Ernesto (Corte Constitucional de Colombia, 23 de abril de 2009).

Sentencia T-832, M. P. Henao Pérez, Juan Carlos (Corte Constitucional de Colombia, 3 de noviembre de 2011).

Sentencia T-904, M. P. Calle Correa, María Victoria (Corte Constitucional, 3de Diciembre de 2013).

Wolfe, A. (1997). Los límites de la legitimidad: contradicciones políticas del capitalismo contemporáneo. España: Siglo XXI Editores. 